\title{
Znaczenie polskiej tradycji administracyjnej dla administracji publicznej III Rzeczypospolitej
}

\begin{abstract}
Abstrakt: Artykuł traktuje o znaczeniu polskiej tradycji administracyjnej dla administracji publicznej III Rzeczypospolitej. Skupiam się w nim na charakterystyce historii polskiej administracji, wskazując, iż dla współczesnego państwa polskiego jedyną rzeczywistą tradycją administracyjną, do której może się ono odwoływać w znaczącym zakresie, są dzieje ustroju i administracji Rzeczypospolitej Polskiej z lat 1918-1939.
\end{abstract}

Słowa kluczowe: administracja publiczna, administracja ogólna, samorząd terytorialny, tradycja administracyjna, model administracji narodowej, III Rzeczpospolita, wojewoda.

Abstract: The article presents the importance of the Polish administrative tradition for the public administration of the Third Polish Republic. I focus on characteristic features of the history of Polish administration, pointing out to the fact that the only actual administrative tradition that could be referred to is the history of political system and administration of the Republic of Poland in 1918-1939.

Keyw ords: public administration, general administration, local government, administrative tradition, model of national administration, Third Polish Republic, voivode.

Dzieje administracji mają znaczący wpływ na organizację i funkcjonowanie współczesnych państw europejskich. W niektórych z nich na przestrzeni wielowiekowego rozwoju wytworzyły się narodowe modele administracji publicznej. Do najważniejszych z nich zaliczamy: francuski, niemiecki, szwedzki, hiszpański, angielski, amerykański. Należy podkreślić, że chociaż budowały się one od wczesnego średniowiecza, ich nowożytny i współczesny kształt, może poza modelem szwedzkim, ukształtował się w XIX w. Właśnie w tym 
okresie ustaliła się klasyczna koncepcja państwa prawnego (Rechtsstaat), w tym i klasyczne zasady oraz instytucje administracji publicznej, które w wieku XX zostały częściowo zmodyfikowane, przede wszystkim w związku $\mathrm{z}$ utrwaleniem się nowych poglądów na pozycję obywatela w państwie i społeczeństwie oraz ze zmianami technik zarządzania. W ich wyniku klasyczne „państwo prawne” przekształciło się po II wojnie światowej w „demokratyczne państwo prawne”, które nazywane również bywa „państwem administracyjnym" (Verwaltungsstaat) ${ }^{1}$.

Tymczasem Polska była w XIX w. pozbawiona samodzielnego bytu państwowego. Utraciła go w 1795 r. i odzyskała dopiero po 123 latach niewoli. W początkach okresu porozbiorowego występowały na jej ziemiach organizmy państwowe, które niezbyt ściśle określa się jako półsuwerenne: Księstwo Warszawskie (1807-1915), konstytucyjne Królestwo Polskie (1815-1830), Wolne Miasto Kraków zwane Rzeczapospolitą Krakowską (1815-1846). Dwukrotnie wystapiły też instytucje suwerennego państwa polskiego: pierwszy raz $\mathrm{w}$ formie właściwej państwu, ze wszystkimi jego atrybutami w okresie powstania listopadowego (1830-1831), drugi raz w szczególnej formie „państwa podziemnego", równoległego do instytucji rosyjskich, w dobie powstania styczniowego (1963-1964). Jednakże wszystkie te organizmy państwowe tylko w niewielkim stopniu mogły nawiązywać do tendencji rozwojowych istniejących $\mathrm{w}$ suwerennych państwach europejskich owego czasu, jak i do dawniejszych rozwiązań polskich sprzed $1795 \mathrm{r}^{2}{ }^{2} \mathrm{~W}$ istocie więc polska tradycja administracyjna może sięgnąc do czasów jedynie przedrozbiorowych oraz Rzeczypospolitej Polskiej z lat 1918-1939.

Dzieje administracji polskiej sprzed 1795 r. należy badać od czasów ukształtowania się ustroju demokracji szlacheckiej i Rzeczypospolitej Obojga Narodów, tj. od połowy XVI w. Jednakże o początkach kształtowania się nowożytnego modelu polskiej administracji publicznej możemy mówić dopiero od połowy XVIII w., kiedy to dzięki reformom administracyjnym w okresie panowania króla Stanisława Augusta Poniatowskiego (1764-1795) Rzeczpospolita szlachecka zbliżała się do rozwiązań charakterystycznych dla osiemnastowiecznych państw europejskich. Rozwiąania polskie miały wiele szczególnych cech pozwalających mówić o ówczesnym polskim modelu administracji publicznej. Był to model władzy obywatelskiej, swoiście demokratycznej, gdyż do 1791 r., tj. do uchwalenia Konstytucji 3 maja, dopuszczał do udziału we władzy politycznej i administracyjnej tylko stan szlachecki

${ }^{1}$ H. Izdebski, M. Kulesza, Administracja publiczna. Zagadnienia ogólne, Warszawa 1999, s. 25-28, 182-188; W. Kozyra, Konstrukcja państwa prawnego w Europie i Polsce na przetomie XIX/XX wieku, „Res Historica” 2011, t. XXXI, s. 47-48; S. Mazur, Narodowe modele administracji publicznej, w: Administracja publiczna, red. J. Hausner, Warszawa 2005, s. 63 i n.

${ }^{2}$ H. Izdebski, M. Kulesza, op. cit., s. 58; J. Kornaś, Administracja publiczna w Polsce, w: Administracja publiczna..., s. 116-120. 
(cives), w Polsce zresztą wyjątkowo liczny w porównaniu z innymi krajami. W $1791 \mathrm{r}$. stworzono szansę stopniowego rozszerzania uprawnień obywatelskich na członków innych stanów, poczynając od bogatszego mieszczaństwa.

Osiemnastowieczny model polskiej administracji publicznej wyróżniał się więc szerokim stosowaniem mechanizmów wyborczych - wyborem przez sejm od 1764 r. coraz większej liczby organów centralnych, a zwłaszcza w latach 1775-1789 faktycznego rządu państwa, czyli Rady Nieustającej. Natomiast sejmiki ziemskie wybierały organy administracji terytorialnej, od $1791 \mathrm{r}$. były to przede wszystkim komisje dobrego porządku. Wybory te łączyły się z szerokimi uprawnieniami kontrolnymi organów wybierających w stosunku do osób i organów wybieranych. Szerokie zastosowanie mechanizmów wyborczych stanowiło zasadniczą różnicę między Rzeczpospolita a ówczesnymi państwami europejskimi. Jedynie pewne podobieństwa można tu było zauważyć w Szwecji w zakresie administracji centralnej i w Anglii w dziedzinie administracji lokalnej (instytucje samorząu terytorialnego). Jednakże, wraz z utrata niepodległości, na ziemie polskie wprowadzone zostały rozwiązania obce ${ }^{3}$.

Instytucje wspomnianego już Księstwa Warszawskiego, stanowiące zresztą próbę przeniesienia na ziemie polskie rozwiązań napoleońskiej Francji, instytucje Królestwa Polskiego (będące w dużej mierze kontynuacją polskiej odmiany modelu francuskiego) czy wreszcie urządzenia administracyjne Rzeczypospolitej Krakowskiej nie mogły wywrzeć wpływu na późniejsze kształtowanie się administracji publicznej na ziemiach polskich. Do czasów I wojny światowej instytucje administracyjne na terytorium byłej Rzeczypospolitej Obojga Narodów rozwijały się bowiem w ramach systemów poszczególnych państw zaborczych - bez nawiązania do jakichkolwiek tradycji polskich. Taki zróżnicowany stan rzeczy, zastany w chwili odzyskiwania przez Polskę niepodległości, musiał więc być punktem wyjścia wszelkich prac nad budowaniem jej nowego zarządu administracyjnego ${ }^{4}$.

W konsekwencji jedynie realną tradycją administracyjną dla współczesnej Rzeczypospolitej Polskiej, nazywana potocznie III Rzeczapospolita, sa dzieje administracji publicznej Rzeczypospolitej Polskiej z lat 1918-1939, określanej też jako II Rzeczpospolita. By gruntownie zaprezentować tę tradycję, w pierwszej kolejności należy pokrótce scharakteryzować podstawy ideowo-doktrynalne i prawne państwa polskiego z lat 1918-1939. Otóż było ono republika konstytucyjna ${ }^{5}$, a jego model ustrojowy ${ }^{6}$ oparty został na

${ }^{3}$ H. Izdebski, M. Kulesza, op. cit., s. 58; J. Kornaś, op. cit., s. 104-116.

${ }^{4}$ H. Izdebski, M. Kulesza, op. cit., s. $57-58$.

${ }^{5}$ S. Krukowski, Mała Konstytucja z 1919 roku, w: Konstytucje Polski. Studia monograficzne z dziejów polskiego konstytucjonalizmu, red. M. Kallas, t. II, Warszawa 1990, s. 7-10.

${ }^{6}$ Najogólniej przez ustrój państwa rozumie się jego prawne zorganizowanie, czyli urządzenie. Ustrój ten określaja następujące elementy: 1) wskazanie suwerena, czyli podmiotu, od którego wywodzi się wszelka władza w państwie; 2) wskazanie organów państwa i ich 
wypracowanym w XIX w. w Europie wzorze państwa liberalnego, określanego również jako państwo prawne, praworządne lub państwo prawa (Rechtsstaat). Wraz z powstaniem konstrukcji państwa prawa z czasem ukształtowała się charakterystyczna dla tegoż modelu struktura administracji publicznej, w tym samorządu terytorialnego ${ }^{7}$.

Początki państwa prawnego sięgaja przełomu XVIII i XIX w., kiedy to rozpoczął się proces przekształcania monarchii absolutnych w monarchie i republiki konstytucyjne. Jego podstawą ideowo-polityczną była doktryna liberalizmu, od zwycięstwa Wielkiej Rewolucji Francuskiej zdobywająca w Europie coraz większe wpływy i znaczenie. Wraz z tym procesem ujawniły się tendencje do przebudowy tradycyjnej administracji terytorialnej w nowoczesna administrację państwową (publiczna). Działalność tej administracji, podobnie jak sądownictwa, poddana została reżimowi norm ustawowych poprzez jej dwustronne związanie normami prawa administracyjnego. Odtąd normy te obowiązywały już nie tylko obywateli, lecz i organy administracyjne (aparat administracyjny). W konsekwencji administracja państwowa, funkcjonując w ramach przepisów prawa i na ich podstawie, poddana została „rządom prawa”. W połowie XIX w. kształtujące się państwo konstytucyjne otrzymało całościową wizję ustrojowa, opracowaną w niemieckim kręgu kultury prawniczej w postaci konstrukcji państwa prawnego lub praworządnego. Było ono $\mathrm{w}$ istocie pragmatyczna kodyfikacją programu liberalnego, dostosowaną do realiów politycznych poszczególnych monarchii i republik konstytucyjnych. Zasadnicze elementy tej konstrukcji to: a) konstytucjonalizm, czyli rządy prawa z najważniejszym aktem prawnym - konstytucją uchwalona przez przedstawicielstwo narodowe będace emanacją suwerennego narodu; b) prawa obywatelskie, na czele z równością wszystkich obywateli wobec prawa; c) wolność gospodarcza, nietykalność własności prywatnej, nietykalność mieszkania; d) wolność myśli, wyznania, sumienia, słowa i druku; e) prawo zrzeszania się, koalicji, bierne i czynne prawo wyborcze, odpowiedzialność polityczna i konstytucyjna ministrów. Z konstrukcji państwa prawnego wynikały zasady, na których zorganizowana została nowożytna i najnowsza administracja publiczna. Były to: 1) zasada biurokratyzmu; 2) zasada centralizacji; 3) zasada decentralizacji - samorządu terytorialnego; 4) zasada resortowości. Następnie: 5) zespolenia; 6) hierarchicznego podporządkowania; 7) jednoosobowego

upoważnień (kompetencji) oraz ich obowiązków; 3) zdefiniowanie relacji między organami państwa. Ustrój państwa w zasadniczy sposób jest określony w konstytucji jako jego statucie organizacyjnym. Konstytucja oprócz uregulowania ustroju państwa normuje ponadto podstawowe prawa i obowiązki obywateli oraz podstawy porządku gospodarczego w państwie, $\mathrm{w}$ tym zwłaszcza stosunki własnościowe. Kompendium wiedzy o społeczeństwie, państwie i prawie, red. S. Wronkowska, M. Zmierczak, Warszawa-Poznań 1995, s. 58-59.

${ }^{7}$ A. Dziadzio, Koncepcja państwa prawa w XIX wieku - idea i rzeczywistość, „Czasopismo Prawno-Historyczne" 2005, t. LVII, z. 1, s. 178-181; W. Kozyra, Konstrukcja państwa prawnego..., s. 51-54. 
kierownictwa; 8) kolegialności; 9) koncentracji; 10) dekoncentracji; 11) nadzoru nad samorządem terytorialnym; 12) sądownictwa administracyjnego ${ }^{8}$. Polska wersje tej konstrukcji gruntowały konstytucje Rzeczypospolitej: pierwsza z 17 III 1921 r. i druga z 23 IV 1935 r. ${ }^{9}$

Prezentując administrację publiczną II Rzeczypospolitej, skoncentruję się na głównej jej części, tj. administracji ogólnej, określanej też jako administracja polityczna lub zespolona. Stanowiła ona „kościec” całej administracji publicznej Polski międzywojennej. Właśnie jej zasady i formy organizacyjne w znaczącym zakresie były recypowane na początku lat dziewięćdziesiatych XX w. przez odradzające się polskie państwo demokratyczne, czyli III Rzeczpospolita.

Administracja ogólna realizowała przede wszystkim zadania należące do resortu spraw wewnętrznych. Jednakże w jej obszar zadań wchodziły również sprawy z zakresu innych resortów administracyjnych (ministerstw), np. zdrowia publicznego, rolnictwa, opieki społecznej, przemysłu i handlu; stąd nazwa: administracja zespolona. Administracja ogólna dzieliła się na dwa szczeble - instancje. Organami I instancji (pierwszego stopnia) byli najpierw komisarze ludowi, później rządowi, a następnie starostowie, starostowie powiatowi (ziemscy) i grodzcy (miejscy). Potocznie organ ten nazywano: starostwem, starostwem powiatowym lub grodzkim, urzędem starosty powiatowego lub grodzkiego, administracja powiatową lub administracja starościńska. Organami II instancji (drugiego stopnia) byli wojewodowie. Organ ten określono również jako województwo, urząd wojewódzki, administracja wojewódzka, administracja wojewódzka - ogólna, zespolona lub polityczna ${ }^{10}$.

Struktura organizacyjna administracji ogólnej powstawała etapami wraz z przejmowaniem poszczególnych terytoriów przez władze odradzającej się Rzeczypospolitej. Jej model organizacyjny i funkcjonalny kształtował się naprzód na obszarze byłego Królestwa Polskiego, a następnie był przenoszony z odpowiednimi modyfikacjami - na pozostałe terytorium Polski. Ostateczna unifikacja administracji ogólnej nastapiła 19 I 1928 r. ${ }^{11}$

Podwaliny administracji politycznej zaczęły kształtować się już podczas I wojny światowej w ramach tworzącego się z woli państw centralnych, czyli Niemiec i Austro-Węgier, Królestwa Polskiego. Przełomowe dla jej powstania

${ }^{8}$ W. Kozyra, Polityka administracyjna ministrów spraw wewnętrznych Rzeczypospolitej Polskiej w latach 1918-1939, Lublin 2009, s. 15; D. Malec, Elementy zasady państwa prawa $w$ Polsce $w$ okresie dwudziestolecia międzywojennego, w: Prawo konstytucyjne II Rzeczypospolitej. Nauka i instytucje, red. P. Sarnecki, Kraków 2006, s. 89.

9 „Dziennik Ustaw” (dalej: DzU) 1921, nr 44, poz. 267; 1935, nr 30, poz. 227.

10 W. Witkowski, Historia administracji w Polsce 1764-1989, Warszawa 2007, s. 331-336; W. Kozyra, Urzqd Wojewódzki w Lublinie w latach 1919-1939, Lublin 1999, s. 10-11.

${ }_{11}$ DzU 1928, nr 11, poz. 86; Historia państwa i prawa Polski 1918-1939, cz. 1, red. F. Ryszka, Warszawa 1962, s. 186-188; R. Hausner, Organizacja władz administracyjnych, „Gazeta Administracji i Policji Państwowej” 1922, nr 24-27. 
było „Orędzie do Narodu” Rady Regencyjnej (RR) z 7 X 1918 r. Jego konsekwencję stanowił dekret RR z 30 X 1918 r. „O organizacji władz na obszarze cesarsko-królewskiego Generalnego Gubernatorstwa Lubelskiego". Upoważniał on ministra spraw wewnętrznych do zorganizowania polskich urzędów powiatowych, które winny przejąć wszelkie prawa i obowiązki cesarsko-królewskich komend powiatowych. Ich szefami mieli być polscy starostowie. Na podstawie upoważnienia rządowego 14 XI 1918 r. minister spraw wewnętrznych ustanowił na terenie okupacji niemieckiej polską administrację powiatowa na czele $\mathrm{z}$ polskimi starostami ${ }^{12}$.

Gdy w Lublinie powstał rząd ludowy Ignacego Daszyńskiego, począł on powoływać na szefów administracji powiatowej nie starostów, ale komisarzy ludowych. Tytuł ten został przejęty przez drugi rząd ludowy, na czele którego stał Jędrzej Moraczewski, oraz rząd Ignacego Jana Paderewskiego. 3 II 1919 r. ukazały się „Tymczasowe przepisy o organizacji urzędów powiatowych”. W art. 2 ustawodawca stwierdzał: „Komisarz Ludowy jest naczelnym kierownikiem administracji politycznej w powierzonym mu powiecie”. Komisarz reprezentował centralna władze państwową i był „organem zarządzającym, rozstrzygającym względnie wnioskującym w sprawach zarządzanych przez Ministerstwo Spraw Wewnętrznych”. Wykonywał nadzór nad samorządem miejskim i wiejskim w granicach przewidzianych przez ustawy. Był zwierzchnikiem urzędów gminnych tak w miastach, jak i wsiach „w poruczonym mu tj. administracyjnym zakresie działania”. Wykonywał władzę zwierzchnia nad „powiatową służbą bezpieczeństwa publicznego” oraz nad powierzonymi mu urzędami i instytucjami państwowymi. Utrzymywał kontakt z urzędami i władzami podległymi bezpośrednio poszczególnym ministerstwom, np. $\mathrm{z}$ inspektorem skarbowym, referentem aprowizacyjnym, inspektorem szkolnym, komisarzem ziemskim, inspektorem pracy, nadleśniczym itp., udzielając im pomocy i egzekwując ich decyzje ${ }^{13}$.

Uściślenie zadań komisarzy ludowych nastapiło w przepisach prawnych, które weszły w życie 26 II i 31 III 1919 r. Regulowały one organizację i funkcjonowanie urzędów powiatowych oraz określały zakres kompetencji komisarza ludowego jako jednoosobowego kierownika organu administracyjnego. Według nich komisarz ludowy reprezentował władze centralne w terenie, kierował pracą urzędów powiatowych oraz realizował kompetencje resortu spraw wewnętrznych. Przepisy te nie rozstrzygały jednoznacznie o zespoleniu w urzędzie komisarza ludowego istniejących na terenie powiatu organów administracji rządowej. Działały więc one nadal jako samodzielne organy

12 „Dziennik Praw Królestwa Polskiego” 1918, nr 15, poz. 33; K.W. Kumaniecki, Odbudowa państwowości polskiej. Najważniejsze dokumenty 1912 - styczeń 1924, Warszawa-Kraków 1924, s. 122-123; R. Hausner, Pierwsze dwudziestolecie administracji spraw wewnętrznych, Warszawa 1939, s. 56.

${ }^{13}$ Archiwum Państwowe w Kielcach, Komisarz Ludowy Kielecki, 3, k. 7, art. 3. 
administracji rządowej. W kwietniu 1919 r. Ministerstwo Spraw Wewnętrznych (MSW) wydało kolejny akt prawny, tj. „Instrukcję dla komisarzy powiatowych”, która znosiła tytuł „komisarza ludowego” na rzecz nowego tytułu: „komisarz rządowy”. Składała się ona z 7 rozdziałów i 74 paragrafów, które dotyczyły: 1) zakresu działania komisarza powiatowego; 2) personelu urzędu powiatowego; 3) stosunku komisarza do innych organów powiatowej administracji państwowej; 4) trybu pracy w urzędzie; 5) składnicy akt i archiwum; 6) przepisów o postępowaniu administracyjnym; 7) przepisów egzekucji administracyjnej ${ }^{14}$.

$\mathrm{Na}$ obszarach podległych urzędom powiatowym działało wiele organów administracji rządowej podporządkowanych bezpośrednio odpowiednim ministerstwom w Warszawie, zazdrośnie strzegących swej niezależności kompetencyjnej. Nie wpływało to dobrze na funkcjonowanie administracji państwowej w terenie. Wytworzyły się z czasem pewien chaos kompetencyjny i przeciążenie pracą ministerstw. Szybko ujawniły się wady jednoinstancyjnej struktury administracji terenowej. Postanowiono wiec powołać drugi szczebel administracji politycznej. Stąd też już 2 VIII 1919 r. sejm uchwalił ustawę tymczasowa „O organizacji władz administracyjnych II instancji” ${ }^{15}$. Ustawa ta powoływała na obszarze byłego Królestwa Polskiego i Okręgu Białostockiego pięć pierwszych województw. Były to województwa: warszawskie, łódzkie, kieleckie, lubelskie i białostockie. Warszawa miała być odrębna jednostką administracyjna (art. 1). Na czele województwa stał wojewoda, mianowany przez naczelnika państwa na wniosek ministra spraw wewnętrznych uchwalony przez Radę Ministrów. Wojewoda był: a) przedstawicielem rządu, sprawującym z jego ramienia władzę państwową i odpowiedzialnym wobec niego za zarząd województwa; b) odpowiedzialnym wykonawcą zleceń poszczególnych ministrów; c) zwierzchnikiem władz i urzędów, które podlegały mu oraz służbowym przełożonym pracowników tych władz i urzędów (art. 2). Ustawa sierpniowa nadawała stanowisku wojewody podwójny charakter: był przedstawicielem rządu (funkcja polityczna) oraz zwierzchnikiem administracji ogólnej na podległym mu terenie (funkcja administracyjna) ${ }^{16}$. W art. 3 ustalono zakres działania wojewody. Należały do niego „wszystkie sprawy administracji państwowej z wyjątkiem spraw przekazanych administracji wojskowej, skarbowej, szkolnej i pocztowo-telegraficznej oraz urzędów ziemskich". Ustawa powoływała przy wojewodzie Radę Wojewódzka, która miała pełnić rolę kolegialnego organu opiniodawczego oraz quasi-przedstawicielstwa samorządu terytorialnego stopnia wojewódzkiego. Składała się ona

${ }_{14}$ „Monitor Polski” (dalej: MP) 1919, nr 76; W. Kozyra, Polityka administracyjna..., s. 83-84.

15 „Dziennik Praw Państwa Polskiego” (dalej: DzPrPP) 1919, nr 65, poz. 395; W. Kozyra, Urzad Wojewódzki w Lublinie..., s. 26.

${ }^{16}$ W. Kozyra, Urzad Wojewódzki w Lublinie..., s. 26; M. Bobrzyński, O zespoleniu dzielnic Rzeczypospolitej, Kraków 1919, s. 9 i n. 
z przedstawicieli sejmików i rad miejskich stanowiących powiaty grodzkie, a wybieranych na okres urzędowania sejmiku względnie rady miejskiej po jednym z każdego z tych ciał oraz z przedstawicieli poszczególnych działów administracji, zarówno wyłączonych spod zwierzchnictwa wojewody, jak i jemu podległych ${ }^{17}$.

Rozporządzenie wykonawcze Rady Ministrów z 13 XI 1919 r. do ustawy tymczasowej z 2 VIII 1919 r. precyzowało następujące zagadnienia: a) stanowisko wojewody i jego stosunek służbowy; b) zakres działania wojewody; c) tok instancji i orzecznictwo wojewody; d) stosunek wojewody do podległych mu urzędów; e) stosunek wojewody do urzędników państwowych na obszarze województwa; f) organizacja Rady Wojewódzkiej; g) organizacja urzędu wojewódzkiego ${ }^{18}$. W art. 6 postanawiano, że na mocy ustaw i rozporządzeń ministerialnych wojewoda mógł w zakresie swej kompetencji wydawać rozporządzenia zawierające sankcje karne do wysokości przewidzianej w odpowiednich przepisach prawa. Dla zabezpieczenia ich wykonalności mogły one przewidywać środki przymusu dopuszczone przez odpowiednie przepisy prawa. Natomiast art. 7 głosił:

Wojewoda zabezpiecza spokój i bezpieczeństwo publiczne na powierzonym mu Woje-
wództwie. Wojewoda decyduje o użyciu oddziałów policji jednego powiatu w granicach
drugiego i o przesunięciu rezerw. W wypadkach wyjątkowych, gdy siły i środki wła-
dzy cywilnej okażą się niewystarczającymi, Wojewoda może zażądać pomocy wojska
[...]. Nadto Wojewoda sprawuje zgodnie z obowiązującymi przepisami nadzór nad
prasa, widowiskami, sprawami paszportowymi, sprawami obcych poddanych, ruchem
ludności, jak też nad zgromadzeniami, stowarzyszeniami i związkami. Wojewoda
prowadzi ponadto rejestrację stowarzyszeń i związków o ile ich działalność ogranicza
się do obszaru Województwa lub jego części.

Artykuły 8-18 precyzowały zakres uprawnień wojewody w sprawach: wojskowych, wyznaniowych, zdrowia publicznego, aprowizacji, ochrony pracy i opieki społecznej, rolniczych i weterynaryjnych, administracji przemysłowej, robót publicznych, gospodarczych oraz samorządu terytorialnego. Omawiane rozporządzenie powoływało do życia aparat pomocniczy wojewody, czyli urząd wojewódzki. W art. 37 ustawodawca postanawiał, że składać się on będzie z departamentów: prezydialnego, administracyjnego, samorządowego, zdrowia publicznego (wojewódzki urząd zdrowia), aprowizacyjnego, rolnictwa i weterynarii, przemysłowego, pracy i opieki społecznej, okręgowej dyrekcji robót publicznych oraz kancelarii głównej. Sprawy należące do zakresu działania Ministerstwa Wyznań Religijnych i Oświecenia Publicznego oraz Ministerstwa Sztuki i Kultury włączone zostały do departamentu administracyjnego. Departamenty miały dzielić się na oddziały. Monokratyczność (jednoosobowość)

${ }_{17}$ DzPrPP 1919, nr 65, poz. 395, art. 1-5.

${ }^{18} \mathrm{DzU}$ 1919, nr 90, poz. 490. 
organu administracyjnego, jakim był wojewoda, i pomocniczość urzędu wojewódzkiego potwierdzano w art. 39, który mówił: „Wszelkie rozporządzenia, polecenia, pisma, podania itp., nadsyłane do Urzędu Wojewódzkiego kierowane są do Wojewody, który je przydziela właściwym urzędnikom do załatwienia. Podobnie wszystkie pisma wychodzące z Urzędu Wojewódzkiego podpisywane są przez Wojewodę lub jego zastępcę względnie upoważnionych przez Wojewodę urzędników”. Pierwsze urzędy wojewódzkie rozpoczęły pracę 15 II 1920 r. ${ }^{19}$

Nastapiła dalsza reorganizacja administracji powiatowej. 28 VIII 1919 r. ukazało się rozporządzenie Rady Ministrów o tymczasowej organizacji powiatowych władz administracyjnych I instancji na obszarze byłego zaboru rosyjskiego ${ }^{20}$. W art. 1 ustawodawca stanowił, że ,powiatowa władza administracyjna I instancji zwie się starostwem”. Natomiast art. 2 stwierdzał: „Na czele starostwa stoi starosta, który jest przedstawicielem władzy państwowej w powiecie. Starostę mianuje Minister Spraw Wewnętrznych”. Sprawował on zarząd powiatu przy pomocy urzędników mianowanych dla poszczególnych działów administracji przez właściwych ministrów względnie wojewodę. Był odpowiedzialnym wykonawca zleceń wojewody i służbowym przełożonym wszystkich urzędników starostwa. Do czasu uruchomienia urzędów wojewódzkich odpowiadał za wykonanie zarządzeń poszczególnych ministrów (art. 3). Artykuł 4 stwierdzał:

\begin{abstract}
Do zakresu działania starosty należą wszelkie sprawy administracji państwowej $\mathrm{z}$ wyjątkiem spraw przekazanych administracji wojskowej, sądowej, skarbowej, szkolnej, kolejowej i pocztowo-telegraficznej oraz urzędom ziemskim. [...] Starosta wydaje, zatwierdza i podpisuje wszystkie rozporządzenia, zarządzenia i orzeczenia starostwa, może jednak poruczyć referentom starostwa w swym zastępstwie wydawanie i podpisywanie zarządzeń i orzeczeń. Rozporządzenia odnoszące się do całej ludności powiatu, poszczególnych miejscowości lub też pewnych grup ludności tudzież zarządzenia i orzeczenia wystosowywane do urzędów publicznych podpisywać może tylko starosta względnie jego zastępca.
\end{abstract}

Urzędy administracji skarbowej i szkolnej, działające w powiecie, powinny projekty rozporządzeń i zarządzeń treści ogólnej, skierowane do urzędów staroście podległych, przesyłać przed ich wydaniem staroście w celu uzyskania jego akceptacji. Gdyby starosta sprzeciwił się ich wydaniu, sprawa miała być przedłożona właściwemu ministrowi względnie wojewodzie, który podejmował ostateczną decyzję w porozumieniu z władzą skarbową lub szkolna II instancji (art. 5).

19 Archiwum Państwowe w Lublinie, Urząd Wojewódzki Lubelski, Wydział Ogólny, 211; MP 1920, nr 54.

${ }^{20}$ DzU 1919, nr 72, poz. 426; J.S. Langrod, Ze studiów nad podziałem administracyjnym państwa, Kraków 1931, s. 12 i n. 
13 XI 1919 r. Rada Ministrów wydała rozporządzenie wykonawcze do rozporządzenia z 28 VIII 1919 r. ${ }^{21}$, gdzie w art. 6 stwierdzała:

\begin{abstract}
Na czele starostwa stoi Starosta mianowany przez Ministra Spraw Wewnętrznych. Starosta podlega dyscyplinarnie Wojewodzie. Pomocniczy personel kancelaryjny Starostwa oraz służbę przyjmuje Starosta. [...] Do starosty należy piecza na spokojem, ładem i bezpieczeństwem publicznym w granicach powierzonego mu powiatu, która sprawuje przy pomocy władz i organów sobie podległych. W wypadkach przewidzianych obowiązującymi ustawami i rozporządzeniami ministerialnymi tudzież na zasadzie upoważnienia udzielonego przez właściwego Wojewodę może Starosta wydawać $\mathrm{w}$ granicach swych kompetencji zarządzenia $\mathrm{z}$ mocą obowiązującą w obrębie danego powiatu. Zarządzenia te mogą zawierać sankcję karną do wysokości przewidzianej odnośnymi ustawami lub rozporządzeniami [art. 8].
\end{abstract}

Akt z 13 XI 1919 r. uszczegóławiał zakres kompetencji starosty. Należały do niego: 1) w powiatach granicznych - czuwanie nad całościa granic państwa; 2) sprawy wojskowe (mobilizacyjne, poborowe, świadczeń na rzecz wojska itp.); 3) ewidencja ludności (sprawy obywatelstwa, przynależności, spisu i ksiag ludności, ruch ludności itp.); 4) sprawy związków i stowarzyszeń; 5) sprawy kosztów leczenia; 6) sprawy bezpieczeństwa publicznego (nadzór nad zgromadzeniami, policja obyczajowa, policja nad uchodźcami i cudzoziemcami, meldunki, paszporty itp.); 7) nadzór nad prasą i widowiskami; 8) sprawy odnoszace się do posiadania, noszenia i handlu bronią i amunicja; 9) sprawy wyznaniowe; 10) sprawy opieki społecznej. Następne kwestie to: 11) ochrony pracy; 12) aprowizacyjne; 13) zdrowotności publicznej; 14) przemysłowe i handlowe; 15) ochrony i popierania rolnictwa; 16) weterynaryjne; 17) polowań i rybołówstwa; 18) budownictwa lądowego, wodnego, dróg kolejowych, pomiarów i ruchu turystycznego; 19) z dziedziny sztuki i kultury; 20) wszystkie te sprawy administracji państwowej, które nie zostały przekazane do załatwienia innym organom lub organom samorządowym; 21) współdziałanie z władzami i organami niepodlegającymi staroście (art. 2).

Starosta był „władzą przełożoną” zarządów gmin i miast w zakresie administracji rządowej. Stąd też magistraty i urzędy gminne musiały stosować się do wszelkich jego wskazówek oraz wykonywać „prawne zalecenia” (art. 4). Organy powiatowe Policji Państwowej podlegały staroście „w zakresie służby bezpieczeństwa i czynności wykonawczych”. W szczególności starosta mógł im wydawać wskazówki i zalecenia, do których winny się one stosować, oraz kontrolował ich merytoryczną działalność (art. 11).

Tak ukształtowana struktura terenowa administracji ogólnej na obszarze ziem centralnych II Rzeczypospolitej (byłego Królestwa Polskiego) była sukcesywnie wprowadzana w życie na pozostałych terytoriach Polski Odrodzonej. Likwidowano jednocześnie istniejącą dotąd administrację państw zaborczych

${ }^{21}$ DzU 1919, nr 90, poz. 489. 
oraz polskie tymczasowe struktury administracyjne. I tak na obszarze byłego zaboru pruskiego, ustawa z dnia 1 VIII 1919 r. „O tymczasowej organizacji byłej dzielnicy pruskiej”, powołano Ministerstwo byłej Dzielnicy Pruskiej oraz dwa województwa: poznańskie i pomorskie ${ }^{22}$. Ministerstwo to działało do 7 IV 1922 r., kiedy to ziemie byłego zaboru pruskiego zostały ostatecznie zintegrowane z pozostałymi częściami państwa ${ }^{23}$. Na obszarze byłego zaboru austriackiego, po zakończeniu walk polsko-ukraińskich o Lwów i Galicję Wschodnia, po likwidacji urzędu Generalnego Delegata Rządu dla b. Galicji, ustawą z 3 XII 1920 r. powołano cztery województwa: krakowskie, lwowskie, tarnopolskie i stanisławowskie. Ich urzędy wojewódzkie rozpoczęły pracę z dniem 1 IX $1921 \mathrm{r} .{ }^{24} \mathrm{Na}$ wschodnich obszarach Rzeczypospolitej nadzór nad administracją ogólną MSW przejęło w latach 1921-1922. Otóż jesienią 1920 r. nastapiła likwidacja Zarządu Cywilnego Ziem Wschodnich, który od wiosny 1919 r. organizował pod nadzorem Naczelnego Dowództwa Wojska Polskiego polską administrację cywilną ${ }^{25}$. Na jego miejsce powołany został Tymczasowy Zarząd Terenów Przyfrontowych i Etapowych (TZTPiE) podlegający bezpośrednio ministrowi spraw wewnętrznych. 18 XI 1920 r. na obszarach podległych TZTPiE powołano trzy okręgi administracyjne: wołyński, poleski i nowogródzki. Zarząd ten postawiony został w stan likwidacji 27 XI 1920 r. Ostatecznie na Kresach Wschodnich z dniem 4 II 1921 r. ustanowiono administrację ogólna, a 1 marca rozpoczęły pracę urzędy wojewódzkie w Łucku, Brześciu nad Bugiem i Nowogródku26. Najpóźniej struktury administracji zespolonej powstały na obszarze Wileńszczyzny. Otóż 9 X 1920 r. polski generał, Lucjan Żeligowski „zbuntował się" i z podległym sobie wojskiem zają Wilno wraz z okręgiem. Następnie na zajętym terytorium utworzył niezależną strukturę państwowa pod nazwa: Litwa Środkowa. Po długim i nierozstrzygniętym sporze dyplomatycznym z państwem litewskim Sejm Litwy Środkowej (Wileński) 20 II $1922 \mathrm{r}$.

${ }^{22}$ DzU 1919, nr 64, poz. 385; Biblioteka Sejmowa (dalej: BS), Sejm Ustawodawczy (dalej: SU), Sprawozdanie stenograficzne, posiedzenie 83 z 1 VIII 1919, p. 2; H. Rasmus, Pommerellen, Westpreußen 1919-1939, München 1989, s. 11 i n.

${ }_{23}$ DzU 1921, nr 24, poz. 199; nr 30, poz. 247; A. Gulczyński, Ministerstwo bytej Dzielnicy Pruskiej (1919-1922), Poznań 1995, s. 213-216.

${ }^{24}$ Archiwum Akt Nowych (dalej: AAN), Prezydium Rady Ministrów (dalej: PRM), Posiedzenie Rady Ministrów (dalej: Pos. RM), t. XIV, k. 402, pos. 57 z 17 V 1921; Dz.U. 1921, nr 115, poz. 762; nr 117, poz. 768; BS, SU, 193, 3 XII 1920, p. 42-43; M. Kozłowski, Między Sanem a Zbruczem. Walki o Lwów i Galicję Wschodnia 1918-1919, Kraków 1990, s. 115.

${ }^{25}$ Derżawnyj Archiw Wołynskoj Obłasti (Archiwum Państwowe Obwodu Wołyńskiego w Łucku), Zarząd Cywilny Ziem Wołynia i Frontu Podolskiego, f. 58, op. 2, spr. 62, ark. 3; Biblioteka Narodowa w Warszawie, J. Osmołowski, Wspomnienia z lat 1914-1921, t. IV: lata 1920-1921 (dalej: BNW, J. Osmołowski, t. IV), akc. 6797, s. 17.

${ }^{26}$ AAN, Kancelaria Cywilna Naczelnika Państwa, 191, k. 8, 10-11; DzU 1921, nr 16, poz. 93; BNW, J. Osmołowski, t. IV, akc. 6797 d, k. 2; W. Kozyra, Ziemia Wotyńska w okresie funkcjonowania administracji Zarzqdu Cywilnego Ziem Wschodnich i Zarzadu Cywilnego Ziem Wotynia i Frontu Podolskiego (1919-1921), „Ucrainica-Polonica” 2004, t. I, s. 183-184. 
podją uchwałę o przyłączeniu jej terytorium do Polski. W odpowiedzi Sejm Ustawodawczy 24 III 1922 r. zdecydował o inkorporowaniu terytorium Litwy Środkowej do Rzeczypospolitej Polskiej ${ }^{27}$. 6 IV 1922 r. weszła w życie ustawa powołująca na Wileńszczyźnie odrębna jednostkę administracyjną na prawach województwa, pod nazwą „Ziemia Wileńska”. Na jej czele stanął komisarz rządowy mający uprawnienia wojewody. Ostatecznie województwo wileńskie wraz z urzędem wojewódzkim powstało 22 XII $1925 \mathrm{r}^{28}$

Województwo śląskie było obszarem autonomicznym utworzonym na mocy ustawy konstytucyjnej z 15 VII 1920 r. Składało się z dwóch terytoriów: a) pięciu powiatów pruskich Górnego Ślaska, które przypadły Polsce na mocy decyzji Rady Ligi Narodów z 12 X 1921 r.; b) dwóch powiatów austriackiego Ślaska Cieszyńskiego, na mocy postanowień Konferencji Ambasadorów w Spa z 28 VII 1920 r. 16 VI 1922 r. województwo śląskie rozpoczęło swoją oficjalna działalnośćc ${ }^{29}$. Administracja spraw wewnętrznych województwa śląskiego bezpośrednio podlegała Radzie Wojewódzkiej, organowi wykonawczemu Sejmu Śląskiego oraz wojewodzie ślaskiemu. Był on jednocześnie reprezentantem rządu polskiego na obszarze województwa ślaskiego i poprzez jego urząd minister spraw wewnętrznych nadzorował śląską administrację wojewódzka i starościńską ${ }^{30}$.

Zasadnicze ujednolicenie administracji ogólnej przyniosło rozporządzenie Prezydenta RP z 19 I $1928 \mathrm{r}^{31}$ Unifikowało ono jej strukturę na obszarze całego państwa $\mathrm{z}$ wyłączeniem województwa śląskiego. Rozporządzenie to utrzymało ustalony już wcześniej podział państwa na 15 województw (bez województwa śląskiego) oraz tworzyło na obszarze Warszawy okręg administracyjny II instancji (de facto województwo miejskie), gdyż dotąd istniała tam tylko administracja ogólna I instancji (art. 85-90). Utrzymywano w zasadzie

${ }^{27}$ Z. Krajewski, „Bunt” generała Żeligowskiego i zajęcie Wilna, „Wojskowy Przegląd Historyczny” R. 41, 1991, nr 1, s. 56-71; W. Kozyra, Polityka Ministra Wnutrisznich Spraw Polskoji Respubliky szczodo schidnych kresiw u 1918-1926 rr., „Ucrainica-Polonica” 2005, t. II, s. 28-29.

${ }^{28}$ Liteuvos Centrinis Valstybės Archyvas (Litewskie Centralne Archiwum Państwowe w Wilnie), Urząd Wojewódzki Wileński Wydział Prezydialny, f. 51, ap. 1, byla - spr. 141, ark. 112, Powiaty województwa wileńskiego na dzień 26 VIII 1924; DzU 1922, nr 26, poz. 213; 1926, nr 6, poz. 29. Szerzej zob. M. Gałędek, Ustrój administracji ogólnej na Wileńszczyźnie w okresie międzywojennym, Gdańsk 2012.

${ }^{29}$ Ustawa konstytucyjna z dnia 15 VII 1920 r. zawierająca Statut Organiczny Województwa Śląskiego. DzU 1920, nr 73, poz. 497. Zob. też: Województwo ślaskie (1922-1939). Zarys monograficzny, red. F. Serafin, Katowice 1996, s. 15-17; Z. Hojka, Podstawy ustrojowe autonomicznego województwa ślaskiego (1922-1939), „Kronika Katowic” 2005, t. X, s. 23-33.

${ }^{30} \mathrm{DzU}$ 1920, nr 73, poz. 497, cz. IV; E. Kaznowska, Kompetencje Ślaskiej Rady Wojewódzkiej - regulacja prawna oraz praktyka (1922-1939), w: Z dziejów prawa, red. A. Lityński, Katowice 1996, s. 174-186.

${ }^{31}$ DzU 1928, nr 11, poz. 86; AAN, Ministerstwo Spraw Wewnętrznych (dalej: MSW), Gabinet Ministra Wydział Organizacyjno-Prawny (dalej: GMWP-O), 473, s. 240. 
dotychczasowy podział państwa na powiaty, w którym Rada Ministrów mogła dokonywać zmian, odtąd także na obszarze województw zachodnich. Powoływano nowe powiaty miejskie w miastach, których ludność przekraczała 75 tys. mieszkańców, z tym, że Rada Ministrów miała prawo powołać taki powiat również w mieście liczącym mniej niż 75 tys. mieszkańców (art. 72-75). W województwie poznańskim podział powiatów na komisariaty obwodowe zastapiono czasowo istniejącymi w województwie pomorskim wójtostwami (art. 105). Warszawa została podzielona na starostwa grodzkie (art. 85). Rządowymi władzami administracji ogólnej II instancji byli wojewodowie i komisarz rządu w Warszawie. Natomiast władze administracji I instancji to starostowie powiatowi, starostowie grodzcy, starosta morski, komisarz rządu w Gdyni. Do władz administracji ogólnej rozporządzenie zaliczało organy samorządowe (komunalne), które spełniały zadania administracji ogólnej $\mathrm{w}$ zakresie nadanym im przez przepisy prawa. Prezydentom miast mogły być przekazane funkcje starostów, a wydziałom powiatowym oraz zarządom miast wydzielonych - zadania administracji drogowej, budowlanej, weterynaryjnej, opieki społecznej, pośrednictwa pracy, spraw wojskowych. Zarząd miasta stołecznego Warszawy mógł otrzymać te same zadania w I i II instancji ${ }^{32}$. Właściwość terytorialna władzy administracyjnej ogólnej obejmowała jej okręg administracyjny. Godząc tę zasadę z potrzebami życia, rozporządzenie przewidywało następujące wyjątki: a) możność powoływania ekspozytur starostw, które urzędowały na określonej części powiatu; b) przekazanie funkcji starosty grodzkiego staroście powiatu ziemskiego sasiadującego z powiatem miejskim; c) na tym samym obszarze mogły istnieć dwie władze powiatowe względnie wojewódzkie (starosta grodzki i prezydent miasta, komisarz rządu i zarzą m.st. Warszawy, starosta powiatowy i wydział powiatowy); d) mogły istnieć organy podległe osobowo jednej władzy administracyjnej, a służbowo kilku (np. Dyrekcja Robót Publicznych we Lwowie obejmowała województwa lwowskie, stanisławowskie i tarnopolskie) ${ }^{33}$.

W rozporządzeniu z 19 I 1928 r. ustawodawca wzmacniał w znaczacy sposób pozycję szefów administracji wojewódzkiej i starościńskiej, tak wobec podległych im struktur administracyjnych, jak i administracji niezespolonej. Stanowił: „Na czele województwa stoi wojewoda, mianowany przez Prezydenta Rzeczypospolitej na wniosek Rady Ministrów przedstawiony jej przez Ministra Spraw Wewnętrznych" (art. 7). Wojewoda podlegał pod względem osobowym ministrowi spraw wewnętrznych, a pod względem służbowym - w zależności od rodzaju spraw wchodzących w zakres jego działania - poszczególnym ministrom właściwym danemu resortowi (art. 8). Zgodnie z art. 9 wojewoda

${ }^{32}$ DzU 1928, nr 11, poz. 86, rozdz. I, IV; AAN, MSW, GMWO-P, 5, Materiały do przepisów wykonawczych rozporządzenia Prezydenta RP z 19 I 1928.

33 AAN, MSW, Gabinet Ministra Sekretariat Ministra, 828; AAN, MSW, GMWO-P, 707, s. 6; DzU 1928, nr 11, poz. 86, rozdz. IV; R. Hausner, Pierwsze dwudziestolecie..., s. 78-79. 
na obszarze województwa był: 1) przedstawicielem rządu sprawującym $\mathrm{z}$ tego tytułu obowiązki przekazane mu tym rozporządzeniem lub specjalnie zlecone przez rząd; 2) szefem administracji ogólnej, tj. administracji spraw wewnętrznych oraz innych działów administracji bezpośrednio zespolonych we władzach administracji ogólnej. Wojewoda jako przedstawiciel rządu miał obowiązek i prawo: a) wyłącznego reprezentowania rządu na wszystkich uroczystych wystapieniach, o ile nie wskazał on innego swego przedstawiciela; b) uzgadniania działalności całej administracji państwowej na obszarze województwa w myśl zasadniczej linii działalności rządu; c) ogólnego nadzoru nad sprawami osobowymi funkcjonariuszy państwowych „ze stanowiska wymogów bezpieczeństwa, spokoju i porządku publicznego"; d) uzgadniania działalności administracji cywilnej oraz interesów gospodarczych województwa z potrzebami obrony państwa. Naczelnicy wszystkich władz i urzędów państwowych, podlegających bezpośrednio władzom centralnym (administracja niezespolona), byli zobowiązani uzgadniać z wojewoda projekty swoich zarządzeń natury ogólnej lub też takich, które miały szczególne znaczenie dla polityki rządu na obszarze województwa (art. 11). Na zaproszenie wojewody i pod jego przewodnictwem naczelnicy władz i urzędów państwowych podległych bezpośrednio władzom centralnym, a niezespolonych z administracją ogólna, powinni odbywać periodyczne zebrania w celu stałego uzgadniania działalności wszystkich działów administracji państwowej między sobą i z zasadnicza linią działalności rządu. W wyjątkowych przypadkach zebrania takie mogły się odbywać dla kilku województw (art. 13).

Do działania wojewody jako szefa administracji ogólnej należały wszystkie sprawy z zakresu: 1) administracji spraw wewnętrznych, tj. administracji bezpośrednio podległej ministrowi spraw wewnętrznych; 2) administracji przemysłu i handlu z wyjątkiem spraw przekazanych administracjom specjalnym, np. administracji górniczej czy morskiej; 3) administracji rolnictwa z szeregiem wyłączeń, np. lasów państwowych, szkolnictwa rolniczego i leśnego itp.; 4) administracji opieki społecznej i pośrednictwa pracy; 5) administracji robót publicznych z wyjątkiem spraw przekazanych dyrekcjom dróg wodnych; 6) administracji spraw wyznaniowych oraz sztuki i kultury (ochrona zabytków itp.). Stosunek wojewody do spraw ubezpieczeń społecznych regulowały odrębne ustawy (art. 27). Wojewoda swoje zadania realizował przy pomocy władz administracji ogólnej oraz innych władz, urzędów i organów mu podległych (art. 28). W art. 29 stwierdzano:

W zakresie spraw administracji ogólnej [...] wojewoda jest: 1) odpowiednim wykonawcą zleceń właściwych ministrów, 2) służbowym zwierzchnikiem odnośnych władz, urzędów i organów oraz przełożonym funkcjonariuszy tych władz, urzędów i organów, 3) organem zarządzającym, orzekającym, rozstrzygającym i stawiającym wnioski, 4) przewodniczącym wszystkich organów kolegialnych (rad, komisji, itp.) powołanych przez obowiąujące przepisy do współdziałania w powyższych działaniach administracji państwowej. 
Wojewoda mianował, przesuwał na inne miejsce służbowe, zwalniał i przenosił w stan spoczynku podległych sobie urzędników do VIII stopnia służbowego włącznie (art. 30). Realizował swoje zadania poprzez udzielanie wskazówek i poleceń władzom administracji ogólnej oraz podległym mu innym władzom i urzędom. Rozstrzygał odwołania od orzeczeń i zarządzeń władz powiatowych i miejskich oraz innych władz i urzędów mu podległych, w ramach przepisów prawnych regulujących właściwość i tok instancji w postępowaniu administracyjnym. Wydawał orzeczenia i zarządzenia w I instancji w wypadkach przewidzianych przez przepisy prawne. Wykonywał nadzór nad działalnością władz administracji ogólnej oraz innych władz i urzędów wojewodzie podległych. Ich decyzje wojewoda mógł uchylać lub zmieniać $\mathrm{z}$ urzędu, w drodze nadzoru $\mathrm{w}$ wypadkach przewidzianych przez przepisy prawne albo ze względu na interes dobra publicznego. Wydawał również powszechnie obowiązujące rozporządzenia i zarządzenia (art. 31). Zastępca wojewody był wicewojewoda - jeden z urzędników urzędu wojewódzkiego z działu administracji spraw wewnętrznych, wyznaczony przez ministra spraw wewnętrznych. Wicewojewoda zastępował wojewodę w zakresie przez niego wyznaczonym. Gdy wojewoda nie mógł pełnić obowiązków służbowych, zakres zastępstwa rozciagał się na wszystkie czynności wykonywane dotąd przez wojewodę (art. 32).

Rozporządzenie prezydenckie z 19 I 1928 r. obszernie regulowało status wojewódzkich organów kolegialnych. Jego art. 40 mówił: „Do współdziałania z wojewodą w wykonywaniu zadań administracji ogólnej w zakresie ustalonym przez przepisy prawne, powołuje się czynnik obywatelski, reprezentowany przez organa samorządu wojewódzkiego". Następnie stwierdzano (art. 41), że do czasu zorganizowania samorządu wojewódzkiego na zasadach ustalonych przez konstytucję marcowa „tworzy się przy wojewodzie radę wojewódzka i wydział wojewódzki, które współdziałają z wojewoda w wykonywaniu jego zadań w zakresie administracji ogólnej, stosownie do postanowień rozporządzenia niniejszego i innych przepisów prawnych". Na marginesie należy dodać, że samorząd wojewódzki, poza ziemiami byłego zaboru pruskiego, nie został wprowadzony w życie do końca istnienia Polski międzywojennej. Stąd też instytucje te pełniły funkcje quasi-organów samorządu wojewódzkiego aż do września 1939 r. W dalszych artykułach (42-63) szczegółowo normowano organizację i zakres działania rad wojewódzkich i wydziałów wojewódzkich.

W rozporządzeniu ze stycznia 1928 r. precyzowano organizację i funkcjonowanie urzędu wojewódzkiego. W art. 33 stwierdzano, że wszyscy funkcjonariusze w urzędzie wojewódzkim oraz we władzach i urzędach państwowych podległych wojewodzie byli na etacie resortu spraw wewnętrznych, z wyjątkiem funkcjonariuszy fachowych, którzy pozostawali na etatach innych ministerstw, a przydzielonych do załatwiania spraw „wymagajacych zawodowej wiedzy fachowej”. W art. 35 konstatowano, że organizacja urzędów 
wojewódzkich opierać się będzie na następujących zasadach: 1) urzędy wojewódzkie dzielą się na niezbędną liczbę wydziałów; 2) wydziały dzielą się w razie koniecznej potrzeby na oddziały; 3) w poszczególnych wydziałach łączy się w miarę możności sprawy jednorodne tak pod względem prawnym, jak i faktycznym; 4) w jednym wydziale pod kierownictwem wicewojewody łączy się sprawy dotyczące organizacji administracji wojewódzkiej, a w szczególności: sprawy osobowe, budżetowe, gospodarcze, inspekcji i nadzoru nad tokiem urzędowania oraz kwestie wynikajace ze stanowiska wojewody jako przedstawiciela rządu; 5) sprawy o charakterze technicznym i techniczno-administracyjnym z działu podległego ministrowi robót publicznych będa załatwiane w osobnym wydziale pod nazwa „Dyrekcja Robót Publicznych”, a kwestie budżetowo-rachunkowe - w odrębnym referacie ogólnym działu rachunkowego. $\mathrm{W}$ art. 36 postanawiano, że $\mathrm{w}$ oparciu o te zasady minister spraw wewnętrznych w porozumieniu z zainteresowanymi ministrami będzie odpowiedzialny za przepisy dotyczące organizacji i trybu załatwiania spraw w urzędach wojewódzkich, a wojewodowie na ich podstawie będą wydawali statuty organizacyjne i szczegółowe podziały czynności urzędów wojewódzkich i ogłaszali je w dziennikach wojewódzkich ${ }^{34}$.

Rozporządzenie Prezydenta RP z 19 I 1928 r. normowało organizacje i funkcjonowanie powiatowych władz administracji ogólnej. Jego art. 64 mówił: „Na czele powiatu stoi starosta powiatowy, mianowany przez Ministra Spraw Wewnętrznych. Starosta powiatowy podlega pod względem osobowym w granicach przepisów regulujących stosunki państwowej służby cywilnej - wojewodzie, względnie Ministrowi Spraw Wewnętrznych pod względem służbowym, zaś - bezpośrednio wojewodzie". Starosta powiatowy na terenie powiatu był przedstawicielem rządu oraz szefem administracji ogólnej, tj. administracji spraw wewnętrznych oraz innych działów administracji bezpośrednio zespolonych we władzach administracji ogólnej. Jako przedstawiciel rządu miał prawo i obowiązek wyłącznego reprezentowania rządu na oficjalnych uroczystościach, o ile rząd nie wysłał osobnego delegata, jak również uzgadniania działalności całej administracji państwowej na obszarze powiatu w myśl zasadniczej linii politycznej rządu (art. 65).

Według rozporządzenia prezydenckiego z 19 I 1928 r. do zakresu pracy starosty powiatowego jako szefa administracji ogólnej należały wszystkie sprawy administracji państwowej na obszarze powiatu, o ile na mocy obowiazujących przepisów nie były zastrzeżone dla właściwości władz naczelnych, wojewody i innych władz państwowych ani nie wchodziły w zakres działania powiatowych związków komunalnych, gmin miejskich i wiejskich oraz obszarów dworskich. W sprawach administracji ogólnej starosta powiatowy był odpowiedzialnym wykonawcą zleceń wojewody, jak również: 1) służbowym

${ }^{34}$ DzU 1928, nr 11, poz. 86; AAN, MSW, GMWO-P, 29, s. 582; W. Kozyra, Polityka administracyjna..., s. 90-92. 
zwierzchnikiem odnośnych władz, urzędów i organów oraz przełożonym ich funkcjonariuszy; 2) organem zarządzajacym, orzekającym, rozstrzygajacym i stawiającym wnioski; 3) przewodniczącym wszystkich organów kolegialnych (rad, komisji itp.) powołanych na mocy obowiąujacych przepisów prawa (art. 67). W art. 68 postanawiano, że „Starosta powiatowy załatwia sprawy należące do jego kompetencji przy pomocy starostwa oraz przy pomocy innych podległych mu na obszarze powiatu władz, urzędów i organów. Starostę powiatowego zastępuje jeden $\mathrm{z}$ urzędników starostwa wyznaczony przez wojewodę". Organizacja urzędu starościńskiego oparta była na analogicznych zasadach jak urzędu wojewódzkiego (art. 69). Na czele starostw grodzkich stali starostowie grodzcy mianowani przez ministra spraw wewnętrznych. Przepisy rozporządzenia z 19 I 1928 r., dotyczące stanowiska i zakresu działania starostów powiatowych, miały analogiczne zastosowanie do starostów grodzkich z wyłączeniem art. 80-84, a gdy chodziło o starostów grodzkich m.st. Warszawy - art. 88-89 ${ }^{35}$. Przy staroście powiatowym funkcjonowały powiatowe organy kolegialne. W art. 89 postanawiano: „Do współdziałania ze starosta powiatowym w wykonywaniu zadań administracji ogólnej powołany jest w zakresie ustalonym przez rozporządzenie niniejsze i przepisy specjalne, czynnik obywatelski, reprezentowany przez organa samorządu powiatowego". Były to sejmiki powiatowe, a od 1933 r. - rady powiatowe ${ }^{36}$.

Rozporządzenie prezydenckie z 19 I 1928 r. z biegiem czasu uległo znacznym modyfikacjom, które można podzielić na zasadnicze (np. sprawa zespolenia pewnych działów administracji) oraz drugorzędne (np. zmiana tytułów poszczególnych urzędników lub nazw organów komunalnych). Dlatego też 25 VIII 1936 r. ukazało się obwieszczenie ministra spraw wewnętrznych, w którym został ustalony znowelizowany, a zarazem jednolity tekst rozporządzenia Prezydenta RP z 19 I 1928 r. ${ }^{37}$

W ostatnich latach II Rzeczypospolitej struktura administracji ogólnej składała się z 17 urzędów wojewódzkich (z Komisariatem Rządu m.st. Warszawy i Ślaskim Urzędem Wojewódzkim) oraz z 264 starostw, w tym 241 powiatowych i 23 grodzkich $^{38}$.

${ }^{35}$ Do Rozporządzenia Prezydenta Rzeczypospolitej Polskiej z 19 I 1928 r. wydano szereg rozporządzeń wykonawczych. W Dzienniku Urzędowym Ministerstwa Spraw Wewnętrznych 1931, nr 16, przekazano do użytku wewnętrznego organom administracji ogólnej całkowity zbiór tych przepisów.

${ }^{36}$ DzU 1928, nr 11, poz. 86, art. 80; 1933, nr 35, poz. 294, art. 1; W. Kozyra, Polska tradycja samorzqdowa $i$ jej wptyw na ksztatt samorzqdu terytorialnego w III Rzeczypospolitej, w: 25 lat polskiej samorzadności. Samorzad terytorialny Europy Środkowo-Wschodniej a model samorzadu terytorialnego dla Ukrainy, red. I. Lasek-Surowiec, Chełm 2016, s. 35-46, 37.

37 AAN, MSW, GMWO-P, 471, s. 713; DzU 1936, nr 80, poz. 555; R. Hausner, Pierwsze dwudziestolecie..., s. 81-82; idem, Nowelizacja rozporzqdzenia Prezydenta RP z 19 stycznia 1928 roku, „Gazeta Administracji” 1936, nr 23-24; W. Kozyra, Urzqd Wojewódzki $w$ Lublinie..., s. 57.

38 AAN, MSW, GMWO-P, 472, s. 517; R. Hausner, Pierwsze dwudziestolecie..., s. 55. 
Po przełomie politycznym w Polsce z 1989 r. (Okragły Stół, wybory kontraktowe z 4 VI 1989 r.) rozpoczęły się proces rozpadu systemu komunistycznego w Polsce i budowa demokratycznego oraz wolnorynkowego państwa polskiego nazywanego powszechnie III Rzeczapospolita. Na przełomie 1989 i 1990 zaczą się też proces budowania nowej polskiej administracji publicznej. Otwierały go dwie fundamentalne ustawy: z 8 III 1990 r. o samorządzie gminnym ${ }^{39}$ i z 22 III 1990 r. o terenowych organach rządowej administracji ogólnej ${ }^{40}$. Pierwsza z nich rozpoczynała rzeczywista przebudowę ustroju polskiej administracji terytorialnej, odrzucając sowiecki model administracji państwowej opartej na systemie rad narodowych, na rzecz polskiego przedwojennego modelu administracji publicznej odwołującej się do konstrukcji państwa prawnego, będącego podstawą współczesnego państwa liberalnego i demokratycznego. Natomiast druga zrywała z peerelowskim modelem rządowej administracji terenowej na rzecz przedwojennego modelu administracji rządowej - ogólnej (politycznej, zespolonej), opartego na rozporządzeniu Prezydenta RP z 19 I 1928 r. o organizacji i zakresie działania władz administracji ogól$n j^{41}$. Model ten odwoływał się również do struktur administracji publicznej, charakterystycznych dla konstrukcji państwa prawnego, będącego podstawa ustrojów państw ówczesnej Europy Zachodniej integrującej się w ramach Wspólnot Europejskich, a następnie w Unii Europejskiej.

Ustawa z 22 III 1990 r. o terenowych organach rządowej administracji ogólnej stanowiła, że zadania administracji rządowej w terenie wykonuja: a) wojewodowie i podporządkowane im organy jako organy administracji ogólnej; b) terenowe organy administracji podporządkowane bezpośrednio ministrom, jako organy administracji specjalnej; c) organy gminy działające w ramach zadań zleconych (art. 1). Natomiast zasadnicze zadania wojewody jako głównego organu administracji rządowej były następujące: 1) reprezentowanie rządu na obszarze województwa; 2) wykonywanie nadzoru nad organami samorządu terytorialnego w trybie i granicach określonych odrębnymi ustawami; 3) rozpatrywanie spraw należących do jego zakresu działania; 4) w postępowaniu administracyjnym pełnienie roli organu wyższego stopnia w rozumieniu przepisów Kodeksu postępowania administracyjnego w stosunku do: a) kierowników rejonowych urzędów rządowej administracji ogólnej; b) organów samorządu terytorialnego $\mathrm{w}$ zakresie realizowanych przez nie zleconych zadań administracji rządowej; 5) załatwianie wszystkich spraw z zakresu administracji rządowej w województwie, niezastrzeżonych dla innych organów tej administracji; 7) wydawanie rozporządzeń, zarządzeń i decyzji administracyjnych (art. 2-4).

Omawiany akt prawny ustanawiał też dodatkowy szczebel administracji rządowej w województwie, tj. rejonowe organy rządowej administracji ogólnej

\footnotetext{
${ }^{39}$ DzU 1990, nr 16, poz. 95.

${ }^{40} \mathrm{DzU}$ 1990, nr 21, poz. 123.

${ }^{41}$ DzU 1928, nr 11, poz. 86; W. Kozyra, Polska tradycja samorzadowa..., s. 39-40.
} 
na czele z kierownikami urzędów rejonowych. Podlegali oni wojewodzie i stanowili I instancje rządowej administracji ogólnej, a wojewodowie - II. Ich zadaniem było wykonywanie określonych w ustawach szczegółowych kompetencji rządowej administracji ogólnej (art. 6).

Ustawa z 22 III 1990 r. stwierdzała, że jednostkami zasadniczego podziału terytorialnego stopnia podstawowego sa gminy, natomiast jednostkami zasadniczego podziału terytorialnego dla wykonywania administracji rządowej - województwa. Natomiast pomocniczą jednostkę w ramach podziału wojewódzkiego stanowił rejon administracyjny (art. 49). W konsekwencji ustawa ta utrzymywała dotychczasowy podział administracyjny państwa na 49 województw ${ }^{42}$.

2 IV 1997 r. Zgromadzenie Narodowe uchwaliło Konstytucję Rzeczypospolitej Polskiej. Stabilizowała ona jej ustrój społeczno-polityczny, a jednocześnie umożliwiała dalsze reformowanie państwa. Już w roku następnym - 1998 - rozpoczęła się więc kolejna faza wielkich reform państwa, realizowana przez rząd postsolidarnościowy Jerzego Buzka. Jedna z nich była reforma administracyjno-samorządowa, która nawiązując do tradycji administracji rządowej i samorządu terytorialnego II Rzeczypospolitej, w ostateczny sposób likwidowała pozostałości ustrojowo-organizacyjne po państwie komunistycznym - Polskiej Rzeczypospolitej Ludowej.

Najważniejszą ustawę tej reformy stanowił akt prawny z 24 VII 1998 r. o wprowadzeniu zasadniczego trójstopniowego podziału terytorialnego państwa. Likwidowała ona dotychczasowy dwustopniowy podział administracyjny państwa na województwa i gminy, wprowadzony 28 V 1975 r. ustawa o dwustopniowym podziale administracyjnym państwa oraz o zmianie ustawy o radach narodowych ${ }^{43}$. W jego miejsce konstytuowała przedwojenny trójstopniowy podział administracyjny państwa na: województwa - powiaty - gminy, który miał obowiązywać od 1 I 1999 r. Akt ten likwidował dotychczasowe 49 województw, a powoływał w ich miejsce 16 nowych. Były to województwa: dolnoślasskie, kujawsko-pomorskie, lubelskie, lubuskie, łódzkie, małopolskie, mazowieckie, opolskie, podkarpackie, podlaskie, pomorskie, śląskie, świętokrzyskie, warmińsko-mazurskie, wielkopolskie, zachodniopomorskie ${ }^{44}$. Następne, przełomowe dla dziejów samorządu terytorialnego w Polsce współczesnej, były ustawy z 5 VI 1998 r. o samorządzie województwa ${ }^{45}$ i o samorządzie powiatowym ${ }^{46}$. Wprowadzały one z dniem 1 I 1999 r., nawiązując do tradycji samorządowej II Rzeczypospolitej, trójstopniową strukturę samorządu terytorialnego, tworząc - oprócz już istniejącego samorządu gminnego - samorząd powiatowy i samorząd wojewódzki.

${ }^{42}$ DzU 1990, nr 21, poz. 123, Załącznik nr 2 do ustawy z 22 marca 1990 r. Wykaz województw, ich nazw oraz siedzib wojewodów.

${ }^{43}$ DzU 1975, nr 16, poz. 91.

${ }^{44}$ DzU 1998, nr 96, poz. 603, art. 1-2.

${ }^{45}$ Ibidem, nr 91, poz. 575.

${ }^{46}$ Ibidem, poz. 578. 
Ustawa z 5 VI 1998 r. o administracji rządowej w województwie umacniała tradycje przedwojennej administracji publicznej w zarządzie administracyjnym współczesnego państwa polskiego. Przede wszystkim normowała ustrój i zasady działania wojewody i administracji zespolonej w województwie oraz organów rządowej administracji niezespolonej" ${ }^{47}$. Według niej od 1 I 1999 r. administrację publiczną w województwie stanowiły: 1) organy administracji rządowej: a) wojewoda sprawujący władzę administracji ogólnej; b) organy administracji niezespolonej; 2) organy samorządu województwa (art. 1). Następnie administrację rządową na obszarze województwa wykonywali: 1) wojewoda; 2) działający pod zwierzchnictwem wojewody kierownicy zespolonych służb, inspekcji i straży, realizujacy zadania i kompetencje określone w ustawach w imieniu: a) wojewody z ustawowego upoważnienia; b) własnym, jeżeli tak ustawy stanowiły; 3) organy administracji niezespolonej; 4) organy samorządu terytorialnego, jeżeli wykonywanie zadań administracji rządowej wynikało z ustaw lub zawartych porozumień; 5) działający pod zwierzchnictwem starosty kierownicy powiatowych służb, inspekcji i straży, wykonujący zadania i kompetencje określone w ustawach; 6) organy innych samorządów, jeżeli wykonywanie zadań administracji rządowej następowało na podstawie ustawy lub porozumienia (art. 2).

Natomiast podstawowy zakres kompetencji wojewody określał art. 7. Wojewoda był: 1) przedstawicielem Rady Ministrów w województwie; 2) zwierzchnikiem zespolonej administracji rządowej; 3) organem nadzoru nad jednostkami samorządu terytorialnego; 4) organem wyższego stopnia w rozumieniu przepisów o postępowaniu administracyjnym, jeżeli ustawy szczególne tak stanowiły; 5) reprezentantem Skarbu Państwa w zakresie i na zasadach określonych w odrębnych ustawach.

Wejście Polski do Unii Europejskiej stało się impulsem do dalszych reform administracji publicznej, których celem było w jeszcze szerszym zakresie wcielanie w życie tradycji administracyjno-samorządowych Rzeczypospolitej Polskiej z lat 1918-1939 oraz wdrażanie do krajowego systemu prawnego przepisów prawa unijnego. Dlatego też 23 I 2009 r. weszła w życie ustawa o wojewodzie i administracji w województwie ${ }^{48}$. W jej świetle wojewoda przede wszystkim był: 1) przedstawicielem Rady Ministrów; 2) zwierzchnikiem rzadowej administracji zespolonej; 3) organem rządowej administracji zespolonej; 4) organem nadzoru nad działalnościa jednostek samorządu terytorialnego i ich związków pod względem legalności; 5) organem administracji rządowej, do którego właściwości należały wszystkie sprawy z zakresu administracji rządowej w województwie, niezastrzeżone w odrębnych ustawach do właściwości innych organów administracji; 6) reprezentantem Skarbu Państwa w zakresie i na zasadach określonych w odrębnych ustawach; 7) organem

${ }^{47}$ Ibidem, poz. 577.

${ }^{48} \mathrm{DzU}$ 2009, nr 31, poz. 206. 
wyższego rzędu w rozumieniu ustawy z 14 VI 1960 r. - Kodeksu postępowania administracyjnego ${ }^{49}$. Wojewoda kontrolował pod względem legalności, gospodarności i rzetelności wykonywanie przez organy samorządu terytorialnego zadań z zakresu administracji rządowej, realizowanych przez nie na podstawie ustaw lub porozumień z organami administracji rządowej. Zadania i kompetencje wojewody w stanach nadzwyczajnych określały odrębne ustawy (art. 3).

Ustawa ze stycznia 2009 r. w sposób niespotykany dotąd w polskim ustawodawstwie, a idąca w duchu rozporządzenia Prezydenta RP z 19 I 1928 r., nadawała wojewodzie wielki zakres uprawnień kontrolnych nad cała administracją rządową i samorządem terytorialnym, działajacych na podległym mu obszarze (art. 28-29). Kontrola ta mogła mieć formę: a) kompleksowej, która obejmowała całą działalność podmiotu kontrolowanego; b) problemowej, która dotykała wybrane zagadnienia podmiotu kontrolowanego; c) sprawdzającej, która dotyczyła sprawdzenia sposobu wykorzystania uwag i wniosków z wcześniejszych kontroli; d) doraźnej, której celem było zbadanie zagadnień wskazanych przez zarządzającego kontrolę; e) koordynowanej, obejmujacej te same zagadnienia w kilku podmiotach kontrolowanych (art. 30). Według postanowień ustawy z 23 I 2009 r. wojewoda sprawował zwierzchnictwo nad cała administracją zespoloną w województwie. Tak więc miał obowiązek kierowania nia, koordynowania jej działalności, a przede wszystkim miał prawo jej kontrolowania. Jednocześnie ponosił odpowiedzialność za rezultaty jej pracy (art. 51).

Podsumowując, należy stwierdzić, że początki polskiej tradycji administracyjnej sięgają czasów staropolskich, a zwłaszcza stanisławowskich. Jednakże rozbiory, które brutalnie przerwały dzieje I Rzeczypospolitej, zablokowały też kształtowanie się polskiego modelu administracji publicznej. Najważniejszy czas dla kształtowania się narodowych modeli administracji publicznej, tj. wiek XIX, naród polski przeżył pod zaborami: rosyjskim, pruskim i austriackim i nie posiadając własnej państwowości, nie mógł tworzyć polskiej wersji administracji publicznej. Dopiero po odrodzeniu się państwa polskiego w 1918 r. mogła ukształtować się i przez 21 lat sprawnie działać polska nowożytna administracja publiczna. Należy podkreślić, że Rzeczpospolita Polska z lat 1918-1939 była nowoczesnym państwem, w którym znalazły zastosowanie rozwiązania ustrojowo-prawne i administracyjne właściwe ówczesnym liberalnym, demokratycznym i prawnym państwom europejskim. Administracja II Rzeczypospolitej była strukturą dualistyczna (dwudziałowa), tj. składała się z administracji rządowej i samorządu terytorialnego. Jej funkcjonowanie zaprezentowałem na przykładzie administracji rządowej, a w szczególności na jej najważniejszej części, czyli administracji ogólnej (politycznej, zespolonej), a która była kośćcem całej administracji publicznej. Właśnie jej zasady

${ }^{49}$ DzU 2000, nr 98, poz. 1071. 
i formy organizacyjne $\mathrm{w}$ zasadniczym zakresie zostały przejęte na początku lat dziewięćdziesiątych XX w. przez odradzajacca się Rzeczpospolitą Polska potocznie nazywaną III Rzeczapospolitą.

Polska Niepodległa z lat 1918-1939 nie wykształciła własnego modelu administracji publicznej, chociaż próby takie zostały podjęte przez reformatorów polskiej administracji, a zwłaszcza przez Komisję dla Usprawnienia Administracji Publicznej (1928-1933) z Maurycym Jaroszyńskim na czele. Jednakże pozostawiła olbrzymią spuściznę prawno-organizacyjna, jak też teoretyczna, która z powodzeniem została wykorzystana przez twórców administracji publicznej Polski demokratycznej po 1989 r.

\section{Streszczenie}

Polska tradycja administracyjna jest bogata, jednakże na jej gruncie nie wykształcił się polski model administracji publicznej. Początki jego kształtowania się - w okresie staropolskim, a zwłaszcza w czasach stanisławowskich - brutalnie przerwały rozbiory Rzeczypospolitej Obojga Narodów i jej ostateczny upadek w 1795 r. Najważniejszy czas dla kształtowania się narodowych modeli administracji publicznej, tj. wiek XIX, naród polski przeżył pod zaborami: rosyjskim, pruskim i austriackim i nie posiadając własnej państwowości, nie mógł tworzyć polskiej wersji administracji publicznej. Dopiero odzyskanie przez Polskę niepodległości w 1918 r. i powstanie Rzeczypospolitej Polskiej (II Rzeczypospolitej), która istniejąc przez 21 lat, zbudowała sprawnie działajacca administrację publiczna, dały podstawy pod konstruowanie takiegoż modelu. Należy podkreślić, że II Rzeczpospolita była nowoczesnym państwem, w którym znalazły zastosowanie rozwiązania ustrojowo-prawne i administracyjne właściwe ówczesnym liberalnym i prawnym państwom europejskim. Organizację i funkcjonowanie administracji publicznej II Rzeczypospolitej przedstawiłem na przykładzie administracji ogólnej (politycznej, zespolonej), która była w istocie jej „kośćcem”. Administracja ogólna realizowała przede wszystkim zadania należące do resortu spraw wewnętrznych. Jednakże do jej kompetencji należały również sprawy z zakresu innych resorów administracyjnych (ministerstw), np. zdrowia publicznego, rolnictwa, opieki społecznej, przemysłu i handlu. W terenie jej organy to: starostowie (I instancja) i wojewodowie (II instancja). Dlatego też właśnie rozwiązania ustrojowe i funkcjonalne administracji ogólnej II Rzeczypospolitej w zasadniczym zakresie były recypowane na początku lat dziewięćdziesiątych XX w. przez odradzające się polskie państwo demokratyczne, tj. Rzeczpospolitą Polską (III Rzeczpospolita). Należy też stwierdzić, że II Rzeczpospolita nie zdążyła ostatecznie wykształcić polskiego modelu administracji publicznej. Jednakże pozostawiła po sobie olbrzymią spuściznę ustrojowo-prawną i administracyjna, jak też teoretyczna, która z powodzeniem mogła zostać i została wykorzystana przy budowie administracji publicznej III Rzeczypospolitej.

\section{Importance of the Polish Administrative Tradition for the Public Administration of the Third Polish Republic}

The Polish administrative tradition is rich, but the Polish model of public administration has not developed on its basis. The beginnings of its formation, which began in the Old Polish period, especially in the reign of King Stanislaus August Poniatowski, were brutally interrupted by the partitions of the Polish-Lithuanian Commonwealth and its final collapse in 1795. During the most important time for the shaping of the national models of public 
administration, i.e. the nineteenth century, the Polish nation was under the Russian, Prussian and Austrian partitions without its own statehood and it could not create the Polish version of public administration.

It was only after the regaining of independence by Poland in 1918 and the establishment of the Republic of Poland (Second Polish Republic), which existed for 21 years and built an efficient public administration, that the basis for constructing such a model was provided. It should be emphasized that the Second Polish Republic was a modern state, in which legal and administrative solutions applicable to the contemporary liberal and legal European countries were enacted. I presented the organization and functioning of the public administration of the Second Polish Republic on the example of a general (political, complex) administration, which was essentially its "skeleton". The general administration primarily carried out the tasks belonging to the Ministry of Internal Affairs. However, its competences also included matters related to other administrative spheres (Ministries) such as public health, agriculture, social welfare, industry and trade. Its local bodies were: starostas (first instance) and voivodes (second instance). All in all, it was the systemic and functional solutions of the general administration of the Second Polish Republic that were essentially recapitulated in the early 1990s by the reviving Polish democratic state, i.e. the Republic of Poland (the Third Polish Republic). It should also be remembered that the Second Polish Republic did not have time to effectively develop the Polish model of public administration. However, it had left a huge systemic, legal, administrative as well as theoretical legacy, which could be, and in fact was, applied in the construction of the public administration of the Third Polish Republic.

\section{Bibliografia}

Bobrzyński M., O zespoleniu dzielnic Rzeczypospolitej, Kraków 1919.

Dziadzio A., Koncepcja państwa prawa w XIX wieku - idea i rzeczywistość, „Czasopismo Prawno-Historyczne" 2005, t. LVII, z. 1, s. 177-201.

Gałędek M., Ustrój administracji ogólnej na Wileńszczyźnie w okresie międzywojennym, Gdańsk 2012.

Gulczyński A., Ministerstwo bytej Dzielnicy Pruskiej (1919-1922), Poznań 1995.

Hausner R., Nowelizacja rozporzadzenia Prezydenta RP z 19 stycznia 1928 roku, „Gazeta Administracji” 1936, nr 23-24.

Hausner R., Organizacja władz administracyjnych, „Gazeta Administracji i Policji Państwowej” 1922, nr 24-27.

Hausner R., Pierwsze dwudziestolecie administracji spraw wewnętrznych, Warszawa 1939.

Historia państwa i prawa Polski 1918-1939, cz. 1, red. F. Ryszka, Warszawa 1962.

Hojka Z., Podstawy ustrojowe autonomicznego województwa ślaskiego (1922-1939), „Kronika Katowic" 2005, t. X, s. 23-33.

Izdebski H., Kulesza M., Administracja publiczna. Zagadnienia ogólne, Warszawa 1999.

Kaznowska E., Kompetencje Ślaskiej Rady Wojewódzkiej - regulacja prawna oraz praktyka (1922-1939), w: Z dziejów prawa, red. A. Lityński, Katowice 1996, s. 174-186.

Kompendium wiedzy o społeczeństwie, państwie i prawie, red. S. Wronkowska, M. Zmierczak, Warszawa-Poznań 1995.

Kornaś J., Administracja publiczna w Polsce, w: Administracja publiczna, red. J. Hausner, Warszawa 2005, s. 103-145.

Kozłowski M., Między Sanem a Zbruczem. Walki o Lwów i Galicję Wschodnia 1918-1919, Kraków 1990.

Kozyra W., Konstrukcja państwa prawnego w Europie i Polsce na przełomie XIX/XX wieku, „Res Historica” 2011, t. XXXI. 
Kozyra W., Polityka administracyjna ministrów spraw wewnętrznych Rzeczypospolitej Polskiej $w$ latach 1918-1939, Lublin 2009.

Kozyra W., Polityka Ministra Wnutrisznich Spraw Polskoji Respubliky szczodo schidnych kresiw u 1918-1926 rr., „Ucrainica-Polonica” 2005, t. II, s. 25-47.

Kozyra W., Polska tradycja samorzqdowa $i$ jej wptyw na ksztatt samorzadu terytorialnego w III Rzeczypospolitej, w: 25 lat polskiej samorzqdności. Samorzqd terytorialny Europy Środkowo-Wschodniej a model samorzadu terytorialnego dla Ukrainy, red. I. Lasek-Surowiec, Chełm 2016, s. 24-40.

Kozyra W., Urzqd Wojewódzki w Lublinie w latach 1919-1939, Lublin 1999.

Kozyra W., Ziemia Wotyńska w okresie funkcjonowania administracji Zarzadu Cywilnego Ziem Wschodnich i Zarzqdu Cywilnego Ziem Wotynia i Frontu Podolskiego (1919-1921), „Ucrainica-Polonica” 2004, t. I, s. 159-169.

Krajewski Z., „Bunt” generała Żeligowskiego i zajęcie Wilna, „Wojskowy Przegląd Historyczny” R. 41, 1991, nr 1 .

Krukowski S., Mała Konstytucja z 1919 roku, w: Konstytucje Polski. Studia monograficzne $z$ dziejów polskiego konstytucjonalizmu, red. M. Kallas, t. II, Warszawa 1990, s. 6-19.

Kumaniecki K.W., Odbudowa państwowości polskiej. Najważniejsze dokumenty 1912 - styczeń 1924, Warszawa-Kraków 1924.

Langrod J.S., Ze studiów nad podziałem administracyjnym państwa, Kraków 1931.

Malec D., Elementy zasady państwa prawa $w$ Polsce $w$ okresie dwudziestolecia międzywojennego, w: Prawo konstytucyjne II Rzeczypospolitej. Nauka i instytucje, red. P. Sarnecki, Kraków 2006, s. 88-99.

Mazur S., Narodowe modele administracji publicznej, w: Administracja publiczna, red. J. Hausner, Warszawa 2005, s. 63-86.

Rasmus H., Pommerellen, Westpreußen 1919-1939, München 1989.

Witkowski W., Historia administracji w Polsce 1764-1989, Warszawa 2007.

Województwo ślaskie (1922-1939). Zarys monograficzny, red. F. Serafin, Katowice 1996.

Bi o g r a m: Waldemar Kozyra - dr hab. prof. nadzw., pracownik Zakładu Historii Społecznej XX wieku Uniwersytetu Marii Curie-Skłodowskiej w Lublinie i Katedry Stosunków Międzynarodowych Państwowej Wyższej Szkoły Zawodowej w Chełmie. Historyk i prawnik, zajmuje się dziejami ustroju i administracji państw doby najnowszej, ze szczególnym uwzględnieniem administracji publicznej Polski XX/XXI w., życiem społeczno-politycznym II RP oraz historią Lubelszczyzny. E-mail: w.kozyra@wp.pl. 